\title{
Response of Some New Hybrids of Maize to Mineral and Organic Fertilization in Reclaimed Soil
}

\author{
Nassar, M. A. A., I. F. Rehab, E. E. Kandil, A.A.A. El-Banna, and \\ K. A.M.M.Nasr \\ Plant production Department, The Faculty of Agriculture (Saba Basha), Alexandria \\ University, Egypt
}

\begin{abstract}
Two field experiments were conducted at North of El Tahrir, El- Behira, Egypt, during 2015 and 2016 seasons, to study the effect of mineral fertilization and organic manure on three maize hybrids. Split plot design with three replications was used, where the main plots contain combination of mineral fertilization (M) + organic manure (OM) i.e., (100\% $\mathrm{M}, 75 \% \mathrm{M}+25 \% \mathrm{OM}, 50 \% \mathrm{M}+50 \% \mathrm{OM}, 75 \% \mathrm{M}+25 \% \mathrm{OM}$ and $100 \% \mathrm{OM}$ ), meanwhile the three maize hybrids (SC.2031, SC.2030 and TWC1100) were allocated in the sub plots. Plot size was $10.50 \mathrm{~m}^{2}(3 \mathrm{~m} \times 3.5 \mathrm{~m})$ having 5 ridges of $3 \mathrm{~m}$ in length and $0.7 \mathrm{~m}$ in width. The obtained results revealed that combined application of $75 \%$ mineral $+25 \%$ organic manure) affected significantly increase in plant height $(\mathrm{cm})$, ear length, number grains/row, number of grains/ear, 100 - grain weight, grain, straw, and biological yield ( $\mathrm{kg} / \mathrm{fed}$.), and harvest index \%. The maize hybrid SC. 2031 recorded the highest means values of above mentioned characters. Fertilizing maize hybrid SC2031 by $75 \%$ mineral $+25 \%$ organic manure gave the highest grain yield and its components under this study.
\end{abstract}

Key words: maize; yield; mineral; organic; fertilization; manure; yield; its components

\section{INTRODUCTION}

Maize (Zea mays L.) is one of the most widely grown cereals in the world. Also, it is important summer grain crops in Egypt. There is wide gap between consumption and local production. This gap could be narrowed through use the high yielding hybrids as well as use optimum organic and mineral fertilization.

Organic farming is an excellent soil amendment which gave a balance of nutrients, while contributing valuable organic material to the soil. Soil microorganisms improved water holding capacity, soil structure for $\mathrm{pH}$ buffering and the organic complexing of nutrients, making them available for plant uptake. It is well documented that the incorporation of organic manure into the soil is increasingly important because it improves soil fertility and increased crop yield (Singh, 2001).

Significant increase in plant height, dry matter, yields and NPK contents with the application of nitrogen fertilizers. Maize growth, dry matter, yields and NPK contents improved significantly when treated compost were added, but it was still below the fertilizer treatments. On comparative basis, maize response was better with FYM (Memon et al., 2012). Maize yield and its components such as number of cobs/plant, cob length, number of grains/cob, and 100- grain weight were maximum when plots were fertilized at $100 \mathrm{~kg} / \mathrm{ha}$., as urea + poultry manure at rate $12.98 \mathrm{t} / \mathrm{ha}$. (Nasim et al., 2012). Application of nitrogen at the rate of $120 \mathrm{~kg} \mathrm{~N} / \mathrm{ha}$ applied as $50 \%$ urea + 50\% FYM can appreciably enhance the growth and yield indices of maize crop. Bilal et al. (2016) concluded that integrated fertilization of nitrogen sources as 50\% FYM and $50 \%$ urea at the rate of $120 \mathrm{~kg} \mathrm{~N} /$ ha resulted in higher yield and yield related traits of 
maize crop and is therefore recommended for achieving higher yield and yield attributes of maize crop.

The soil with organic manure continually applied had lower bulk density and higher porosity values, porous and buffering capacities (Edmeades, 2003).Proper application of organic and inorganic fertilizers can increase the activities of soil microorganisms and enzymes and soil available nutrient contents (He and Li, 2004; Saha et al., 2008).

100 grain weight, yield and yield components and $\mathrm{N}, \mathrm{P}$ and $\mathrm{K}$ of maize plants were increased significantly by increasing the level of nitrogen up to 140 $\mathrm{kg} \mathrm{N} / \mathrm{fed}$ (Siam et al., 2008) Nitrogen levels had significant effects on yield and yield components in maize hybrids (Sharifi and Taghizadeh, 2009). The level of nitrogen fertilization differentiated the chlorophyll content expressed in SPAD units (Szulc and Hubert, 2010). 100 grain weight, grain yield and straw yield increased with increasing the rate of $\mathrm{N}$ fertilizer up to $120 \mathrm{~kg} \mathrm{~N} / \mathrm{ha}$. Treatment of $120 \mathrm{~kg} \mathrm{~N} / \mathrm{fed}$ in four doses as 40, 20, 20 and $20 \%$ added after 14, 28, 48, and 56 days after sowing (DAS), recorded higher values of 100 grain weight, straw and grain yield of maize (El-Agrodi et al., 2011).

$\mathrm{N}$ and $\mathrm{P}$ levels significantly increased the studied parameters of corn plants as compared with control. The highest values were obtained by using $120 \mathrm{~kg} \mathrm{~N}+35 \mathrm{~kg} \mathrm{P} 2 \mathrm{O}_{5} /$ fed., followed by $80 \mathrm{~kg} \mathrm{~N}+25 \mathrm{~kg} \mathrm{P_{2 }} \mathrm{O}_{5} /$ fed., and $40 \mathrm{~kg}$ $\mathrm{N}+15 \mathrm{~kg} \mathrm{P} \mathrm{O}_{5} /$ fed (Ibrahim and Hala, 2007).

The Single Cross 3084 significantly surpassed other hybrids in number of grains/ear, ear weight, grain weight/ear and grain yield/fed. It was noticed that the maximum values of plant and 100-grain weight, ear weight, grain yield/fed were obtained by application of $120 \mathrm{~kg} \mathrm{~N} / \mathrm{fed}$ as a mineral form. Whereas, no significant difference was noticed between $90 \mathrm{~kg} \mathrm{~N}$ min.+30 kg N org./fed and $120 \mathrm{~kg} \mathrm{~N} \mathrm{min/fed} \mathrm{on} \mathrm{most} \mathrm{characters} \mathrm{studied} \mathrm{in} \mathrm{both} \mathrm{seasons} \mathrm{(El-Gizawy} \mathrm{and}$ Salem, 2010).

The objective of this investigation was to study the impact of organic manure for new maize hybrids as sown reclaimed soil on yield and its components and their interaction.

\section{MATERIALS AND METHODS}

Two field experiments were carried out to study the effect of mineral fertilization and organic manure on yield, yield components of three maize hybrids and their interaction. Field experiments were conducted at North of El Tahrir, El-Beheara Governorate, Egypt, during the two successive seasons 2015 and 2016.

A split plot with three replications was used whereas main plots were combination of mineral fertilization (M) and organic manure (OM) namely; $100 \%$ mineral fertilization (120 kg N/fed, $24 \mathrm{~kg} \mathrm{P}_{2} \mathrm{O}_{5} / \mathrm{fed}$ and $24 \mathrm{~kg} \mathrm{~K} \mathrm{~K}_{2} \mathrm{O} / \mathrm{fed}$.), 75\% mineral (90 kg N/fed,18 kg $\mathrm{P}_{2} \mathrm{O}_{5} / \mathrm{fed}$ and $\left.18 \mathrm{~K}_{2} \mathrm{O} \mathrm{kg} \mathrm{K} \mathrm{K}_{2} \mathrm{O} / \mathrm{fed}\right)+25 \%$ organic manure (2.5 ton/fed), $50 \%$ mineral (60 kg N/fed, $12 \mathrm{~kg} \mathrm{P} / \mathrm{fed}$ and $12 \mathrm{~kg} \mathrm{~K} \mathrm{~K}_{2} \mathrm{O} / \mathrm{fed}$ ) 
$+50 \%$ organic manure (5 ton/fed.), $25 \%$ mineral (30 kg N/fed, $6 \mathrm{~kg} \mathrm{P/fed}$. and 6 $\mathrm{kg} \mathrm{K} \mathrm{K}_{2} \mathrm{O} / \mathrm{fed}$.) $+75 \%$ organic manure $(7.5$ ton/fed) and $100 \%$ organic manure (10 ton/fed) while the three maize hybrids namely; Single cross 2031 (S.C. 2031), single cross 2030 (SC. 2030) and three way cross (TWC.1100) were distributed in subplot. Plot size was $10.50 \mathrm{~m}^{2}(3 \mathrm{~m} \times 3.5 \mathrm{~m})$ having 5 ridges of 3 $\mathrm{m}$ in length and $0.7 \mathrm{~m}$ in width. Two grains were hand planted in each hill. Plant spacing 25 spacing $25 \mathrm{~cm}$ between plants.

Some physical and chemical characteristics of the studied soil before sowing are presented in Table (1) which were determined according to Klute (1986).

Mineral fertilization consists of nitrogen as in form of ammonium nitrate $\left(\mathrm{NH}_{4} \mathrm{NO}_{3} 33.5 \%\right)$, phosphorus as calcium super phosphate $\left(15.5 \% \mathrm{P}_{2} \mathrm{O}_{5}\right)$ and potassium as potassium sulphate $\left(48 \% \mathrm{~K}_{2} \mathrm{O}\right)$.

Organic manure (cow manure) at the one rate was added (10 tons/fed) at the soil preparation before planting in both seasons analysis of organic manure is presented in Table (2).

Table (1). Some physical and chemical properties of the experimental soil sites during 2015 and 2016 seasons

\begin{tabular}{|c|c|c|}
\hline \multicolumn{3}{|c|}{ Soil parameter } \\
\hline & \multicolumn{2}{|c|}{ Season } \\
\hline & 2014 & 2015 \\
\hline \multicolumn{3}{|l|}{ Particle size distribution \% } \\
\hline Sand & 58.40 & 57.10 \\
\hline Silt & 11.00 & 11.1 \\
\hline Clay & 30.60 & 31.10 \\
\hline Textural class & Sandy loam & Sandy loam \\
\hline Chemical properties: & 792 & 800 \\
\hline $\begin{array}{l}\mathrm{pH}(1: 1) \text { (soil: water suspension) } \\
\mathrm{EC}(1: 1) \text { (soil: water extract), dS/m }\end{array}$ & 3.70 & 3.80 \\
\hline Soluble cations $(1: 2)(\mathrm{meq} / \mathrm{l})$ & & \\
\hline $\mathrm{K}^{+}$ & 0.46 & 0.48 \\
\hline $\mathrm{Ca}^{++}$ & 2.60 & 2.50 \\
\hline $\mathrm{Mq}^{++}$ & 3.50 & 3.40 \\
\hline $\mathrm{Na}^{++}$ & 12.10 & 12.50 \\
\hline \multicolumn{3}{|l|}{ Soluble anions (1:2) (meq/l) } \\
\hline $\mathrm{HCO}_{3}^{-}$ & 6.00 & 6.60 \\
\hline $\mathrm{CL}$ & 8.00 & 8.20 \\
\hline $\mathrm{SO}_{4}^{-}$ & 4.40 & 4.00 \\
\hline Calcium carbonate, $\%$ & 21.25 & 19.85 \\
\hline Total nitrogen, \% & 0.75 & 0.85 \\
\hline Available P (mg/kg) & 4.42 & 4.55 \\
\hline Organic matter, \% & 1.47 & 1.45 \\
\hline
\end{tabular}


Table (2).Composition of organic manure (cow manure)

\begin{tabular}{lcc}
\hline \multicolumn{1}{c}{ Determination } & Cow manure & Unit \\
\hline Moisture & 13.70 & $\%$ \\
Organic matter (\%) & 62.93 & $\%$ \\
Total N & 1.20 & $\%$ \\
Total P & 1.40 & $\%$ \\
Total K & 1.10 & $\%$ \\
pH $(1: 5)$ & 8.35 & - \\
EC $(1: 5)$ & 1.40 & $\mathrm{dS} / \mathrm{m}$ \\
C:N & $30.4: 1$ & - \\
\hline
\end{tabular}

Planting dates were on $25^{\text {th }}$ May in 2015 and 2016 cropping seasons, respectively.

Phosphorus fertilizer was applied before planting. Field was hand thinned before the first irrigation to one plant/hill. The experimental units were hand hoed twice for controlling weeds before the first and second irrigations. $\mathrm{N}$ fertilizer was applied in two equal doses, the first dose was before the first irrigation and the second one was before the second irrigation during cropping seasons. Potassium sulphate $\left(48 \% \mathrm{~K}_{2} \mathrm{O}\right)$ was added before the first irrigation.

All other agricultural treatments for maize plants were done as recommended by the Egyptian Ministry of Agriculture. Preceding crop was wheat in both seasons.

Plant height and yield traits were determined at harvest time after 120 days from planting, three medium ridges (36 plants), which were taken from each sub plot in which grain yield was determined on the basis of $15.5 \%$ moisture and the following data were recorded: Plant height $(\mathrm{cm})$, ear length $(\mathrm{cm})$, number of grains /row, number of grains /ear, 100 - grain weight (g), grain yield, straw yield, biological yield (kg/fed), and harvest index (\%).

Data were subjected to analysis of variance according to Gomez and Gomez (1984). All statistical analysis was performed using analysis of variance technique by means of CoStat computer software package (CoStat, Ver. 6.311., 2005). The least significant differences (LSD at 0.05) used to compare the treatment means.

\section{RESULTS AND DISCUSSION}

Data in Table (3) revealed the effect of combination of mineral and organic fertilization and their interaction on plant height $(\mathrm{cm})$, ear length $(\mathrm{cm})$ and number of grains/row for the three maize hybrids during 2015 and 2016 seasons.

With regard to the effect of mineral fertilization and organic manure affected significantly in plant height, ear length and number of grains/row of the maize in both seasons, whereas application of $75 \%$ mineral fertilization and 
$25 \%$ organic manure recorded the highest mean values for these traits followed by application of $100 \%$ mineral fertilization, respectively, during two seasons (Table 3). He and Li (2004) indicated that combined application of organic and inorganic fertilizers can increase the activities of soil and available nutrient content which increased growth and yield attributes of plants. Also, Kandil (2004) revealed that using organic fertilizer caused significant increases in plant height, ear length and number of kernels/row of maize.

Also, Table (3) revealed that there was significant difference among the three maize hybrids on plant attributes namely; plant height, ear length number of grains/row in both growing seasons. Where, the SC. 2031 achieved the tallest plant height, ear length and the highest mean value of number of grains/row. Variations in grain number might be due to differences in genetic potential of maize hybrids. On the other side there was no significant difference among the three maize hybrids in the first season. These results are in harmony with Kandil (2013) who indicated that there was significant difference among maize hybrids in plant height $(\mathrm{cm})$, ear length $(\mathrm{cm})$ and number grains/row.

The data in Table (3) indicated that there was significant interaction between the combination of mineral + organic manure on plant height $(\mathrm{cm})$, ear length $(\mathrm{cm})$ and number of grains/row. Whereas the highest mean values for plant height, ear length and number of grains/row were obtained from SC. 2031 when fertilization $75 \%$ mineral $+25 \%$ organic manure in seasons 2015 and 2016. Meanwhile the lowest one recorded with TWC $1100+100 \%$ organic manure during two seasons. On the other hand there is no significant interaction between two factors on ear length in the first season. 
Table (3). Average of plant attributes for three maize hybrids as affected by mineral fertilization (M), organic manure (OM) and their interaction during 2015 and 2016 seasons

\begin{tabular}{|c|c|c|c|c|c|c|c|c|c|c|c|c|c|c|c|}
\hline \multirow{3}{*}{ Attributes } & \multirow{3}{*}{$\begin{array}{c}\text { Fertilizer } \\
\text { treatments (F) }\end{array}$} & \multicolumn{7}{|c|}{ Season 2015} & \multicolumn{7}{|c|}{ Season 2016} \\
\hline & & \multicolumn{3}{|c|}{ Maize hybrid $(\mathrm{H})$} & \multirow{2}{*}{$\begin{array}{c}\text { Average } \\
\text { (F) }\end{array}$} & \multicolumn{3}{|c|}{ LSD at 0.05} & \multicolumn{3}{|c|}{ Maize hybrid (H) } & \multirow{2}{*}{$\begin{array}{c}\text { Average } \\
\text { (C) }\end{array}$} & \multicolumn{3}{|c|}{ LSD at 0.05} \\
\hline & & $\begin{array}{l}\text { SC. } \\
2031\end{array}$ & $\begin{array}{l}\text { SC. } \\
2030\end{array}$ & $\begin{array}{l}\text { TWC } \\
1100\end{array}$ & & $\mathbf{F}$ & $\mathbf{H}$ & $\mathbf{F} \times \mathbf{H}$ & $\begin{array}{c}\text { SC. } \\
2031\end{array}$ & $\begin{array}{c}\text { SC. } \\
2030\end{array}$ & $\begin{array}{l}\text { TWC } \\
1100\end{array}$ & & $\mathbf{F}$ & $\mathbf{H}$ & FxH \\
\hline \multirow{5}{*}{$\begin{array}{l}\text { Plant height } \\
(\mathrm{cm})\end{array}$} & $100 \%$ Mineral & 346.7 & 326.7 & 283.2 & $318.9 \mathrm{a}$ & \multirow{6}{*}{11.4} & \multirow{6}{*}{6.8} & \multirow{6}{*}{15.4} & 336.3 & 328.7 & 316.0 & $327.0 \mathrm{a}$ & \multirow{6}{*}{11.9} & \multirow{6}{*}{7.0} & \multirow{6}{*}{15.6} \\
\hline & $75 \% \mathrm{M}+25 \% \mathrm{OM}$ & 346.7 & 326.7 & 298.3 & $323.9 a$ & & & & 339.0 & 330.0 & 314.0 & $327.7 a$ & & & \\
\hline & $50 \mathrm{M}+50 \mathrm{OM}$ & 336.7 & 326.7 & 303.3 & $322.2 \mathrm{a}$ & & & & 324.7 & 315.7 & 300.3 & $313.6 b$ & & & \\
\hline & $25 \mathrm{M}+75 \mathrm{OM}$ & 286.7 & 299.3 & 303.7 & $296.6 b$ & & & & 309.7 & 310.0 & 311.7 & $310.5 b$ & & & \\
\hline & $100 \%$ OM & 305.3 & 321.0 & 283.3 & \multirow{2}{*}{$303.2 b$} & & & & 317.3 & 310.0 & 278.0 & $301.8 b$ & & & \\
\hline \multicolumn{2}{|c|}{ Average $(\mathrm{H})$} & \multicolumn{3}{|c|}{$324.4 a$ 320.1a 294.4b } & & & & & \multicolumn{3}{|c|}{$325.4 a$ 318.9a 304.0b } & & & & \\
\hline \multirow{5}{*}{$\begin{array}{l}\text { Ear length } \\
(\mathrm{cm})\end{array}$} & $100 \%$ Mineral & 23.4 & 25.2 & 23.4 & \multirow{5}{*}{$\begin{array}{l}24.0 a \\
24.6 a \\
22.0 b \\
18.9 c \\
18.5 c\end{array}$} & \multirow{6}{*}{1.3} & \multirow{6}{*}{1.1} & \multirow{6}{*}{ ns } & 22.5 & 24.6 & 23.5 & $23.5 b$ & \multirow{6}{*}{0.10} & \multirow{6}{*}{0.16} & \multirow{6}{*}{0.22} \\
\hline & $75 \% \mathrm{M}+25 \% \mathrm{OM}$ & 25.0 & 25.4 & 23.3 & & & & & 24.5 & 24.9 & 23.4 & $24.3 a$ & & & \\
\hline & $50 \mathrm{M}+50 \mathrm{OM}$ & 22.2 & 22.2 & 21.7 & & & & & 22.1 & 21.0 & 22.0 & $21.7 c$ & & & \\
\hline & $25 \mathrm{M}+75 \mathrm{OM}$ & 21.0 & 18.9 & 16.8 & & & & & 19.7 & 21.0 & 18.1 & $19.6 d$ & & & \\
\hline & $100 \%$ OM & 19.3 & 18.3 & 17.8 & & & & & 20.1 & 19.0 & 18.0 & $19.0 \mathrm{e}$ & & & \\
\hline \multicolumn{2}{|c|}{ Average (H) } & $22.2 \mathrm{a}$ & $22.0 a$ & $20.6 b$ & \multirow{7}{*}{$\begin{array}{c}50.6 a \\
49.3 a b \\
48.2 b \\
43.3 c \\
41.6 c\end{array}$} & & & & $21.8 \mathrm{~b}$ & $22.1 \mathrm{a}$ & $21.0 \mathrm{c}$ & & & & \\
\hline & $100 \%$ Mineral & 49.3 & 49.3 & 53.3 & & & & & 52.0 & 49.0 & 49.7 & $50.2 a$ & & & \\
\hline & $75 \% M+25 \% O M$ & 52.0 & 48.7 & 47.3 & & & & & 53.7 & 50.3 & 48.0 & $50.7 a$ & & & \\
\hline Number OT & $50 \mathrm{M}+50 \mathrm{OM}$ & 47.7 & 51.0 & 46.0 & & & & & 46.0 & 45.7 & 50.7 & $47.5 b$ & & & \\
\hline & $25 \mathrm{M}+75 \mathrm{OM}$ & 43.3 & 40.0 & 46.7 & & 2.3 & ns & 3.9 & 44.0 & 41.0 & 42.0 & $42.3 c$ & 0.46 & 0.42 & 3.9 \\
\hline & $100 \% \mathrm{OM}$ & 41.3 & 42.7 & 40.7 & & & & & 44.0 & 40.7 & 40.0 & $41.6 d$ & & & \\
\hline Av & erage (H) & 46.7 & 46.3 & 46.8 & & & & & $47.9 a$ & $45.3 c$ & $46.1 \mathrm{~b}$ & & & & \\
\hline
\end{tabular}

Mean values in the same column/row marked with the same letters are not significantly different at 0.05 level of probability.

- ns.: not significant difference at 0.05 level of probability according to LSD. 
Table (4) showed the effect of mineral and organic fertilization and their interaction on number of grains/ear, 100- grain weight $(\mathrm{g})$ and grain yield (kg/fed.) for the three maize hybrids in 2015 and 2016 seasons.

With regard to the effect of mineral fertilization and organic manure, it is significantly affected number of grains/ear, 100- grain weight and grain yield (kg/fed.) of maize in both seasons, whereas $75 \%$ mineral and $25 \%$ organic manure recorded the highest mean values for number of grains/ear (in the second season only), 100- grain weight and grain yield in two seasons (Table 4).In this respect Kandil (2004) revealed that using organic fertilizer caused significant increases in yield and its components of maize. These findings agreed with Siam et al. (2008), Szulc and Hubert (2010), Memon et al. (2012), and Bilal et al. (2016).

Table (4) reported that there was significant difference among the three hybrids on number of grains/ear, 100- grain weight and grain yield (kg/fed.) in both cropping seasons. Where, the SC. 2031 gave the highest number of grain/ear and grain yield in two seasons. While the highest value of 100- grain weight recorded with TWC1100 in both season. While Sc.203 recorded the lowest one in 2015 and 2016. Variations in grain number might be due to differences in genetic potential of maize hybrids. These findings are in agreement with El-Gizawy and Salem (2010), Ahmed (2011), and Kandil (2013) who indicated that there was significant difference among maize hybrids in 100grain weight, grain yield and number grains/ear.

The interaction between the combination of mineral + organic manure on number of grains/ear, 100- grain weight and grain yield ( $\mathrm{kg} / \mathrm{fed}$.) were significant (Table 4). Whereas the highest values for number of grains/ear in both season, and grain yield ( $\mathrm{kg} / \mathrm{fed}$.) in the first season only were obtained from SC. 2031 when fertilization $75 \%$ mineral $+25 \%$ organic manure in seasons 2015 and 2016 .on the other wiseTWC $1100+75 \%$ mineral $+25 \%$ organic recorded the heaviest $100+$ grain weight in two seasons. Meanwhile the lowest one recorded with TWC $1100+100 \%$ organic manure during two seasons. On the other hand there is no significant interaction between two factors on grain yield/fed in the second season. 
Table (4). Average of plant attributes for maize hybrids as affected by mineral fertilization (M),organic manure (OM) and their interaction during 2015 and 2016 seasons

\begin{tabular}{|c|c|c|c|c|c|c|c|c|c|c|c|c|c|c|c|}
\hline \multirow{3}{*}{ Attributes } & \multirow{3}{*}{$\begin{array}{c}\text { Fertilizer } \\
\text { treatments (F) }\end{array}$} & \multicolumn{7}{|c|}{ Season 2015} & \multicolumn{7}{|c|}{ Season 2016} \\
\hline & & \multicolumn{3}{|c|}{ Maize hybrid $(\mathrm{H})$} & \multirow{2}{*}{$\begin{array}{c}\text { Averag } \\
\text { e (F) }\end{array}$} & \multicolumn{3}{|c|}{ LSD at 0.05} & \multicolumn{3}{|c|}{ Maize hybrid $(\mathrm{H})$} & \multirow{2}{*}{$\begin{array}{l}\text { Average } \\
\text { (F) }\end{array}$} & \multicolumn{3}{|c|}{ LSD at 0.05} \\
\hline & & $\begin{array}{l}\text { SC. } \\
2031\end{array}$ & $\begin{array}{l}\text { SC. } \\
2030\end{array}$ & $\begin{array}{l}\text { TWC } \\
1100\end{array}$ & & $\mathbf{F}$ & $\mathbf{H}$ & $\mathbf{F} \times \mathrm{H}$ & $\begin{array}{c}\text { SC. } \\
2031\end{array}$ & $\begin{array}{l}\text { SC. } \\
2030\end{array}$ & $\begin{array}{l}\text { TWC } \\
1100 \\
\end{array}$ & & $\mathbf{F}$ & $\mathbf{H}$ & F $\times H$ \\
\hline \multirow{5}{*}{$\begin{array}{l}\text { Number of } \\
\text { grains/ear }\end{array}$} & $100 \%$ Mineral & 690.7 & 592.0 & 746.7 & \multirow{6}{*}{$\begin{array}{c}676.5 \mathrm{a} \\
658.2 \mathrm{ab} \\
639.7 \mathrm{~b} \\
580.0 \mathrm{c} \\
553.3 \mathrm{c}\end{array}$} & \multirow{6}{*}{32.3} & \multirow{6}{*}{23.7} & \multirow{6}{*}{52.9} & 728.0 & 588.0 & 695.3 & $670.4 a$ & \multirow{6}{*}{6.1} & \multirow{6}{*}{5.4} & \multirow{6}{*}{12.2} \\
\hline & $75 \% M+25 \% O M$ & 728.0 & 584.0 & 662.7 & & & & & 751.3 & 604.0 & 672.0 & $675.8 \mathrm{a}$ & & & \\
\hline & $50 \mathrm{M}+50 \mathrm{OM}$ & 667.3 & 612.0 & 6.44 .0 & & & & & 644.0 & 548.0 & 709.3 & $633.8 b$ & & & \\
\hline & $25 \mathrm{M}+75 \mathrm{OM}$ & 606.7 & 480.0 & 653.3 & & & & & 616.0 & 492.0 & 588.0 & $565.3 c$ & & & \\
\hline & $100 \% \mathrm{OM}$ & 578.7 & 512.0 & 569.3 & & & & & 616.0 & 488.0 & 560.0 & $554.7 d$ & & & \\
\hline \multicolumn{2}{|c|}{ Average (H) } & $654.3 a$ & $556.0 \mathrm{~b}$ & $658.0 \mathrm{a}$ & & & & & $671.1 \mathrm{a}$ & $544.0 c$ & $644.9 b$ & & & & \\
\hline \multirow{5}{*}{$\begin{array}{l}100 \text { grain } \\
\text { weight }(g)\end{array}$} & $100 \%$ Mineral & 42.6 & 42.4 & 45.2 & \multirow{6}{*}{$\begin{array}{l}43.4 b \\
45.3 a \\
43.5 c \\
40.4 d \\
39.5 e\end{array}$} & \multirow{6}{*}{0.14} & \multirow{6}{*}{0.15} & \multirow{6}{*}{0.34} & 43.4 & 43.5 & 45.5 & $44.1 \mathrm{~b}$ & \multirow{6}{*}{0.17} & \multirow{6}{*}{0.16} & \multirow{6}{*}{0.37} \\
\hline & $75 \% M+25 \% O M$ & 44.2 & 44.7 & 47.1 & & & & & 46.0 & 44.7 & 47.7 & $46.1 \mathrm{a}$ & & & \\
\hline & $50 \mathrm{M}+50 \mathrm{OM}$ & 41.8 & 41.7 & 47.1 & & & & & 40.2 & 41.9 & 41.2 & $41.1 \mathrm{c}$ & & & \\
\hline & $25 \mathrm{M}+75 \mathrm{OM}$ & 41.1 & 40.8 & 39.2 & & & & & 38.9 & 40.4 & 38.9 & $39.4 \mathrm{e}$ & & & \\
\hline & $100 \% \mathrm{OM}$ & 40.0 & 39.8 & 38.7 & & & & & 42.2 & 39.2 & 39.2 & $40.2 d$ & & & \\
\hline \multicolumn{2}{|c|}{ Average (H) } & $41.9 b$ & $41.9 \mathrm{~b}$ & $43.5 a$ & & & & & $42.1 \mathrm{a}$ & $41.9 \mathrm{~b}$ & $42.5 a$ & & & & \\
\hline & $100 \%$ Mineral & 2751.9 & 2915.6 & 2694.5 & \multirow{6}{*}{$\begin{array}{l}2787.3 b \\
2971.4 a \\
2426.8 c \\
2196.7 d \\
2027.9 e\end{array}$} & & & & 2785.5 & 2840.3 & 2712.3 & $2779.4 b$ & \multirow{6}{*}{151.3} & \multirow{6}{*}{112.7} & \\
\hline & $75 \% \mathrm{M}+25 \% \mathrm{OM}$ & 3095.1 & 3094.1 & 2725.1 & & & & & 2850.5 & 3056.8 & 3020.5 & $2975.9 a$ & & & \\
\hline Grain yield & $50 \mathrm{M}+50 \mathrm{OM}$ & 2438.5 & 2598.5 & 2243.5 & & & & & 2827.2 & 2700.5 & 2617.2 & $2715.0 b$ & & & \\
\hline & $25 \mathrm{M}+75 \mathrm{OM}$ & 2338.5 & 2078.5 & 2173.1 & & 17.4 & 17.1 & 38.9 & 2640.5 & 2487.2 & 2153.8 & $2427.2 c$ & & & ns \\
\hline & $100 \%$ OM & 2285.1 & 2040.1 & 1758.5 & & & & & 2377.2 & 2470.5 & 2313.8 & $2387.2 c$ & & & \\
\hline Av & erage (H) & $2581.8 a$ & $2545.4 b$ & $2318.9 c$ & & & & & $2696.2 a$ & $2711.1 \mathrm{a}$ & $2563.5 b$ & & & & \\
\hline
\end{tabular}


Data in Table (5) reported that the effect of mineral fertilization and organic manure and their interaction was significant on straw yield, biological yield (kg/fed.) and harvest index (HI \%) of three maize hybrids in 2015 and 2016 seasons.

The effect of mineral fertilization and organic manure significantly affected the straw yield, biological yield ( $\mathrm{kg} / \mathrm{fed}$.) and harvest index $(\mathrm{HI} \%)$ in both seasons, whereas application of $75 \%$ mineral fertilization and $25 \%$ organic manure recorded the highest mean values for straw and biological yields while $100 \%$ mineral fertilization gave the highest value of $\mathrm{HI} \%$ in two seasons (Table 5). These findings agreed with Kandil (2004), Siam et al. (2008), Szulc and Hubert (2010), El-Agrodi et al. (2011), Nasim et al. (2012) and Bilal et al. (2016).who showed that yield and its components of maize increased by application of organic fertilizer.

The results in Table (5) stated that the three maize hybrids had significant difference in straw yield, biological yield ( $\mathrm{kg} / \mathrm{fed}$.) and harvest index $(\mathrm{HI} \%)$ in both growing seasons. Whereas, the hybrid SC. 2031 recorded the heaviest straw yield, and biological yield ( $\mathrm{kg} / \mathrm{fed}$.) in both seasons. Meanwhile the highest $\mathrm{HI} \%$ was given with Sc.2030 in the first season, only. Variations in grain number might be due to differences in genetic potential of maize hybrids. On the other side there was no significant difference among the three maize hybrids in the first season. The obtained results are in confirmed with Kandil (2013) who indicated that there was significant difference among maize hybrids in straw and biological yields as well as $\mathrm{HI} \%$.

The findings in Table (5) revealed the significant interaction between the combination of mineral + organic manure on straw yield, biological yield (kg/fed.) and harvest index ( $\mathrm{HI} \%)$. Whereas the highest mean values for straw yield in the second season, were obtained from SC. 2031 when fertilization $25 \%$ mineral $+75 \%$ organic manure. On the other hand the highest value of biological yield (kg/fed.) and harvest index (HI \%) were given with Sc. $2031+$ $75 \% \mathrm{M}+25 \% \mathrm{Om}$ in the first season, only. Meanwhile the lightest straw yield recorded with Sc. $203+1 \%$ OM in the first season, TWC $1100+100 \%$ organic manure in 2016 season. However the lowest biological yield/fed was obtained with fertilizing Sc.2030 by $100 \%$ organic manure in the first season only. On the other hand there is no significant interaction between two factors on straw yield in the first season, on biological yield/fed in the second season, and on $\mathrm{HI} \%$ in the first and second seasons. 
Table (5). Average of plant attributes for maize hybrids as affected by mineral (M), organic manure (OM) fertilization and their interaction during 2015 and 2016 seasons

\begin{tabular}{|c|c|c|c|c|c|c|c|c|c|c|c|c|c|c|c|}
\hline \multirow{3}{*}{ Attribute } & \multirow{3}{*}{ Fertilizer (F) } & \multicolumn{7}{|c|}{ Season $2014 / 2015$} & \multicolumn{7}{|c|}{ Season 2015/2016 } \\
\hline & & \multicolumn{3}{|c|}{ Maize hybrid (H) } & \multirow{2}{*}{$\begin{array}{c}\text { Average } \\
\text { (H) }\end{array}$} & \multicolumn{3}{|c|}{ LSD at 0.05} & \multicolumn{3}{|c|}{ Maize hybrid (H) } & \multirow{2}{*}{$\begin{array}{l}\text { Average } \\
\text { (C) }\end{array}$} & \multicolumn{3}{|c|}{ LSD at 0.05} \\
\hline & & $\begin{array}{l}\text { SC. } \\
2031\end{array}$ & $\begin{array}{l}\text { SC. } \\
2030\end{array}$ & $\begin{array}{l}\text { TWC } \\
1100\end{array}$ & & $\mathbf{F}$ & $\mathbf{H}$ & F $\times H$ & $\begin{array}{l}\text { SC. } \\
2031\end{array}$ & $\begin{array}{l}\text { SC. } \\
2030\end{array}$ & $\begin{array}{l}\text { TWC } \\
1100\end{array}$ & & $\mathbf{F}$ & $\mathbf{H}$ & F $\times H$ \\
\hline \multirow{5}{*}{$\begin{array}{l}\text { Straw yield } \\
\text { kg/fed. }\end{array}$} & $100 \%$ Mineral & 4091.4 & 3662.0 & 3983.3 & $3912.2 b$ & \multirow{6}{*}{219.1} & \multirow{6}{*}{203.6} & \multirow{6}{*}{ ns } & 3526.5 & 4391.7 & 3791.7 & 3903.3a & \multirow{6}{*}{198.4} & \multirow{6}{*}{230.9} & \multirow{6}{*}{519.9} \\
\hline & $75 \% \mathrm{M}+25 \% \mathrm{OM}$ & 4816.9 & 4160.6 & 4234.0 & $4403.8 \mathrm{a}$ & & & & 3557.5 & 3846.4 & 3795.5 & $3733.1 \mathrm{ab}$ & & & \\
\hline & $50 \mathrm{M}+50 \mathrm{OM}$ & 3897.6 & 4121.6 & 3624.6 & $3881.3 b$ & & & & 3524.8 & 3347.5 & 3230.8 & $3367.7 c$ & & & \\
\hline & $25 \mathrm{M}+75 \mathrm{OM}$ & 3925.6 & 3733.2 & 3757.6 & $3805.5 b c$ & & & & 4219.6 & 3311.5 & 3174.5 & $3568.5 b$ & & & \\
\hline & $100 \% \mathrm{OM}$ & 3757.6 & 3393.6 & 3526.1 & \multirow{2}{*}{$3559.1 c$} & & & & 3133.8 & 3025.5 & 2806.2 & $2988.5 d$ & & & \\
\hline \multicolumn{2}{|c|}{ Average (H) } & $4097.8 \mathrm{a}$ & $3814.2 b$ & $3825.1 \mathrm{~b}$ & & & & & $3592.4 a$ & $3584.5 a b$ & $3359.7 b$ & & & & \\
\hline \multirow{5}{*}{$\begin{array}{c}\text { Biological } \\
\text { yield } \\
(\mathrm{kg} / \mathrm{fed})\end{array}$} & $100 \%$ Mineral & 6843.3 & 6577.6 & 6677.8 & \multirow{6}{*}{$\begin{array}{l}6699.6 b \\
7375.3 a \\
6308.1 c \\
5833.4 d \\
5755.8 d\end{array}$} & \multirow{6}{*}{218.9} & \multirow{6}{*}{203.2} & \multirow{6}{*}{457.7} & 6312.0 & 7232.0 & 6504.0 & $6682.7 a$ & \multirow{6}{*}{317.9} & \multirow{6}{*}{258.1} & \multirow{6}{*}{ ns } \\
\hline & $75 \% \mathrm{M}+25 \% \mathrm{OM}$ & 7912.0 & 7254.7 & 6959.1 & & & & & 6408.0 & 6903.2 & 6816.0 & $6709.1 a$ & & & \\
\hline & $50 \mathrm{M}+50 \mathrm{OM}$ & 6336.1 & 6720.1 & 5868.1 & & & & & 6352.0 & 6048.0 & 5848.0 & $6082.7 b$ & & & \\
\hline & $25 \mathrm{M}+75 \mathrm{OM}$ & 6210.7 & 5773.3 & 5516.1 & & & & & 6860.1 & 5798.7 & 5328.3 & $5995.7 b$ & & & \\
\hline & $100 \%$ OM & 6096.1 & 5472.1 & 5699.2 & & & & & 5511.0 & 5496.0 & 5120.0 & 5375.7c & & & \\
\hline \multicolumn{2}{|c|}{ Average (H) } & $6679.6 a$ & $6359.6 b$ & $6144.1 \mathrm{c}$ & & & & & $6288.6 a$ & $6295.6 a$ & $5923.3 b$ & & & & \\
\hline & $100 \%$ Mineral & 6843.3 & 6577.6 & 6677.8 & \multirow{6}{*}{$\begin{array}{l}41.6 a \\
40.3 b \\
38.5 c \\
38.2 c \\
34.7 d\end{array}$} & \multirow{6}{*}{1.3} & \multirow{6}{*}{1.2} & & 44.1 & 39.3 & 41.7 & $41.7 b$ & & & \\
\hline & $75 \% \mathrm{M}+25 \% \mathrm{OM}$ & 7912.0 & 7254.7 & 6959.1 & & & & & 44.5 & 44.3 & 44.3 & $44.4 a$ & & & \\
\hline index & $50 \mathrm{M}+50 \mathrm{OM}$ & 6336.1 & 6720.1 & 5868.1 & & & & & 44.5 & 44.7 & 44.8 & $44.6 a$ & & & \\
\hline & $25 \mathrm{M}+75 \mathrm{OM}$ & 6096.1 & 5472.1 & 5699.2 & & & & ns & 38.5 & 42.9 & 40.4 & $40.6 b$ & ns & 1.9 & ns \\
\hline & $100 \% \mathrm{OM}$ & 6210.7 & 5773.3 & 5516.1 & & & & & 43.1 & 45.0 & 45.2 & $44.4 \mathrm{a}$ & & & \\
\hline Av & erage (H) & $6679.6 \mathrm{~b}$ & $6359.6 a$ & $6144.1 \mathrm{~b}$ & & & & & 42.9 & 43.2 & 43.3 & & & & \\
\hline
\end{tabular}
$6679.6 \mathrm{~b} 6359.6 \mathrm{a} 6144.1 \mathrm{~b}$

- Mean values in the same column/row marked with the same letters are not significantly different at 0.05 level of probability.

ns: not significant difference at 0.05 level of probability according to LSD. 


\section{CONCLUSION}

It can be concluded that fertilizing maize hybrid Sc. 2031 by $75 \%$ mineral fertilization $+25 \%$ organic manure achieved the highest values of yield and its components under study conditions.

\section{REFERENCES}

Ahmed, Howida E.A. (2011). Effect of spatial distribution of plant under different watering regimes on the yield and its components of corn (Zea mays L.). M.Sc. Thesis, Agron. Dept. Fac. Agric., Assiut Univ. Egypt.

Bilal, M., A.Ahmad, A. Shan and A. Jalal (2016). Enhancing maize yield through integration of organic and inorganic nitrogen fertilizers. Int. J. Agric. Environ. Res., 2(2): 153-161.

CoStat Ver. 6.311 (2005). Cohort software798 light house Ave. PMB320, Monterey, CA93940, and USA. email: info@cohort.com and Website: http://www.cohort.com/DownloadCoStatPart2.html

Edmeades DC (2003). The long-term effects of manures and fertilizers on soil productivity and quality: a review. Nut. Cyc. Agroecosys., 66: 165-180.

GOP (2010). Economic Survey of Pakistan (2009-10). Ministry of Finance, Islamabad, Pakistan.

El-Agrodi, M. W., A. M. El-Ghamry and W. M. Lashin (2011). Maize response to nitrogen rate and splitting in sandy clay loam soil. J. Soil Sci. and Agric. Eng., Mansoura Univ., 2 (11):1129-1139.

El-Gizawy, N.Kh.B. and H.M. Salem (2010). Influence of Nitrogen Sources on Yield and its Components of Some Maize Varieties. World Journal of Agricultural Sci., 6 (2): 218-223.

Gomez, A. K. and A. A. Gomez (1984). Statistical Procedures for Agricultural Research. (2nd edition). John Wiley and Sons. New York.

He, Y. and R. Li (2004). Effect of the organo-inorgano-mixed fertilizer application on sugarcane yield and soil enzymatic activity. Sugar Crops China, 4: 36-38.

Ibrahim, S.A and Hala, Kandil (2007). Growth, yield and chemical constituents of corn (Zea mays L.) as affected by nitrogen and phosphors fertilization under different irrigation intervals. J. Appl. Sci. Res., 3(10): 1112-1120.

Kandil, E.E. (2004). A comparative study of bio- and organic fertilization on maize. MSc. Thesis, Fac. Agric. (Saba Basha), Alex.Un.

Kandil, E.E. (2013). Response of some maize hybrids (Zea mays L.) to different levels of nitrogenous fertilization. J. Appl. Sci. Res., 9(3): 1902-1908.

Klute, A. (1986). "Methods of Soil Analysis". Part 1, Soil Physical Properties. ASA and SSSA, Madison, WI.

Memon, M., K.S. Memon, S. Mirani and G.M. Jamro (2012). Comparative evaluation of organic wastes for improving maize growth and NPK content. African J. Biotech., 11(39): 9343-9349. 
Nasim, W., A. Ahmad, T. Khaliq, A. Wajid, M.Farooq, H. Munis, H.J. Chaudhry,M.M. Maqbool, S. Ahmad and H.M. hammad (2012).Effect of organic and inorganic fertilizer on maize hybrids under ogro- environmental conditions of Faisalabad Pakistan, Afric. J. Agric., Res., 7(12):2713-2719.

Saha, S., V. Prakash, S. Kundu, N. Kumar, B.L.Mina (2008). Soil enzymatic activity as affected by long-term application of farmyard manure and mineral fertilizer under a rainfed soybean-wheat system in N-W Himalaya. Eur. J. Soil Biol., 44: 309-315.

Sharifi, R. S. and R. Taghizadeh (2009). Response of maize (Zea mays L.) cultivars to different levels of nitrogen fertilizer. J. of Food Agric. \& Environ., 7 (3\&4): $518-521$.

Siam, H. S.; M. G. A. El-Kader and H. I. El-Alia (2008). Yield and yield components of maize as affected by different sources and application rates of nitrogen fertilizer. Res. J. Agric. and Bio. Sci., 4 (5): 399-412.

Singh, B.P. (2001).Effect of lak mud, farm yard manure and inorganic fertilizers on growth and yield of rice (Oryza sativa L.). Agric. Sci. Digest., 21(1):21-24.

Szulc, P. and W. Hubert (2010). Response of maize hybrid (Zea mays L.), staygreen type to fertilization with nitrogen, sulphur, and magnesium part II. Plant development and the uptake of mineral components. Acta Sci. Pol., Agric., 9 (1): 41-54.

الملخص العربى

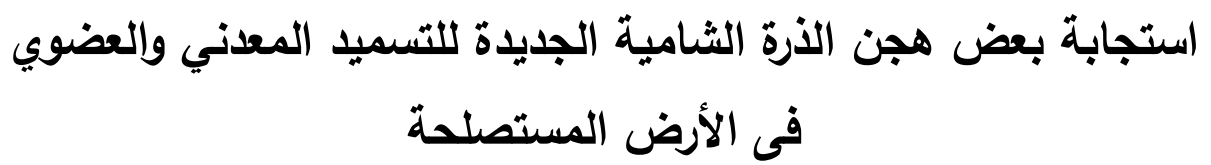

محمد أحمد عبد الجواد نصار ، ابراهيم فتح الله رحاب ، عصام اسماعيل قنديل ،

على أحمدعلي الصاوي البنا ، كمال عبد المنعم محمد إبراهيم نصر

قسم الأنتاج النباتي - كلية الزراعة ساباباشا - جامعة الأسكندرية - مصر

أقيمت تجربتان حقليتان بمزرعة خاصة بمنطقة شمال التحرير - محافظة البحيرة - مصر خلال موسمى الزراعة

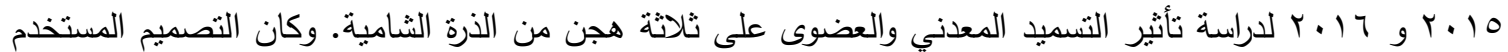

هو القطع المنشقة مرة واحدة فى ثلاثة مكررات حيث وزعت معاملات مكونه من نوليفة السماد المعدني والعضوي فى ملى

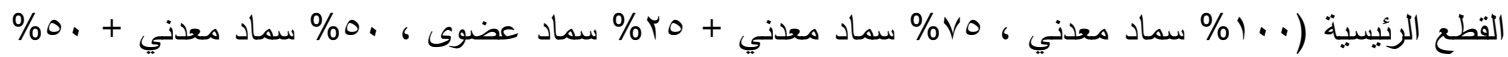

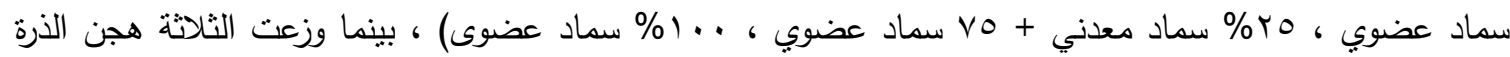


الثنامية (انتاج شركة هاي ناك) فى القطع تحت الرئيسية ( هجين فردى اب.r ، هجين فردي •r.r ، وهجين ثلاثي .$(1) \cdots$

\section{ويمكن تليخص أهم النتائج فيما يلي:}

- أظهرت توليف المعاملات من التسميد المعدني والعضوى تأثير معنوي على ارتفاع النبات ، طول الكوز وعدد الحبوب/صف و عدد الحبوب/كوز ووزن . ـ حبة ومحصول الحبوب والقش والمحصول البيولوجي ودليل الحصاد ،

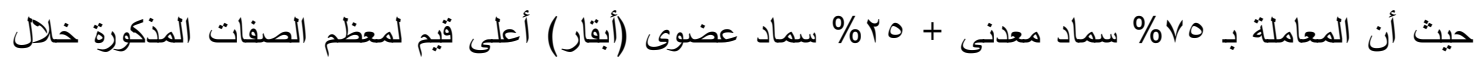
موسمي الزراعة. - ـ وجد أن هناك اختلاف معنوي بين الثثلاثة هجن من الذرة الثامية فى معظم الصفات الددروسة خلاد موسمي الدراسة

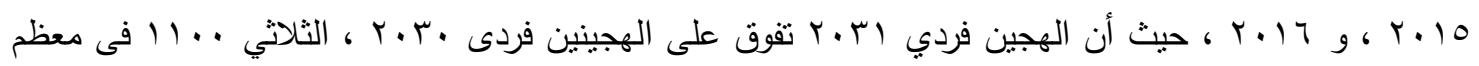

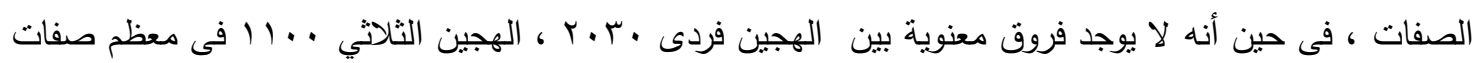
المحصول ومكوناته للذرة الثنامية خلال موسمي الزراعة.

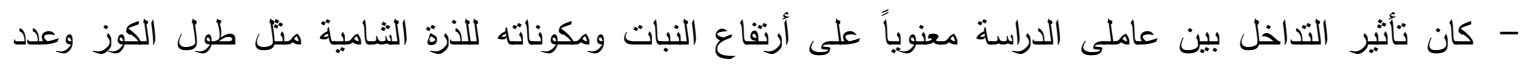

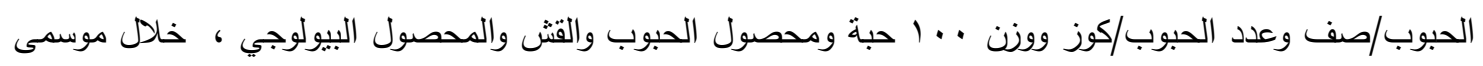

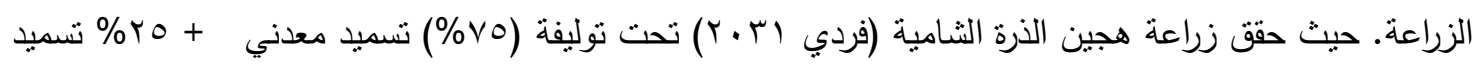
عضوي أعلى قيم لهذه الصفات.

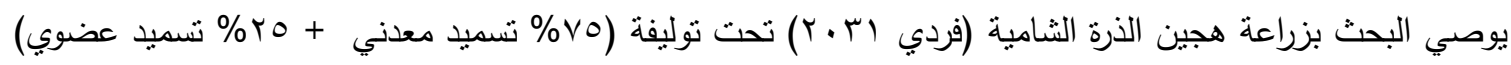
حيث حققت تلك المعاملة أعلى قيم لصفات المحصول ومكوناته تحت ظروف الأراضى الجديدة بمنطقة شمال التحرير

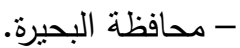


